\title{
Right product pricing: Application of activity-based costing (ABC)-and- economic value added (EVA) as an integrated tool
}

\author{
Nikhil Chandra Shil ${ }^{1}$ and Bhagaban Das ${ }^{2 *}$ \\ ${ }^{1}$ Department of Accounting, American International University, Bangladesh. \\ ${ }^{2}$ Department of Business Management, Fakir Mohan University, Orissa, India. \\ Accepted 12 September, 2012
}

\begin{abstract}
The traditional activity based costing $(A B C)$ can be used as a more powerful and accurate pricing tool if integrated with economic value added (EVA), a value-based financial performance measure. The paper is targeted to discus the integrated $A B C$-and-EVA system that is considered as an engineering management tool used successfully to manage both cost and capital. It allows enterprise leaders to create shareholders value through cost structure improvement. In this integrated system, the cost of activities includes an equitable charge for the consumption of resources at one end and charge for capital demanded and used at the other end. The implementation process of the system is discussed and a comparison with the traditional $A B C$ system is made to make it simple and decisive to the users. The process starts with the identification of activities and then income statement and balance sheet data is adjusted in line with EVA approach. This information is then transformed into transparent capital charges using activity-capital dependence $(A C D)$ analysis, which has been added with the costs of each activity to have integrated total costs. The paper concludes with a discussion of possible changes to corporate strategies and business performance when the integrated $A B C$-and-EVA system is implemented in a manufacturing company for pricing their products.
\end{abstract}

Key words: Activity-based costing $(A B C)$, economic value added $(E V A)$, residual income $(R l)$, activity-capital dependence $(A C D)$, engineering management tool.

\section{INTRODUCTION}

Privately held for-profit organizations run all of their dealings solely to make money in the present and over the long run. If any of such company is not able to generate enough economic profit over time, its survival is questionable in the long run. Moreover, companies making little or no profit are not very attractive for potential investors looking for returns. Management always has to satisfy the investors by proper utilization of their funds and generating economic value in terms of accurate, not virtual or accounting profit. Accounting profit is a concept that may not, sometimes, add value to the current wealth of the investors. Thus a move towards

\footnotetext{
${ }^{*}$ Corresponding author. E-mail: bhagaban_fm@yahoo.co.in.
}

real improvement and value creation is demanded as opposed to clever manipulation of financial data for shortterm performance gains.

The quality of an organization's cost information is highly related to overall business performance (Dearden, 1963). Activity-based costing $(A B C)$, a costing system that has recently gained popularity is based on a simple idea: in an enterprise, overhead (or operating) expenses are generated by a number of activities needed to perform manufacturing and business processes successfully. Since activities consume resources, and products (or projects or processes) demand activities, the cost of products is related to the cost of resources (Cooper, 1988a, b; 1989a, b). In many cases, the ABC implementtation has contributed substantially to a more efficient use of resources, and therefore, has lead to an impressive 
cost savings (Cooper and Kaplan, 1991). By design, $A B C$ provides not only relatively accurate cost data, but also information about the origin of the cost (Cooper and Kaplan, 1988). Till date, $A B C$ has been implemented in numerous companies, and managers familiar with the $A B C$ method were able to manage costs more successfully. Costs were kept in-line through the removal of non-value-added activities, process improvement, or outsourcing. $A B C$, which is able to reliably trace overhead expenses, disregards capital cost, however. In other words, $A B C$ only focuses on data included in a company's income statement, and fully disregards the balance sheet (Roztocki and Needy, 1999b). Even the most impressive cost reductions, however, do not automatically imply an improvement in value creation; often the shareholder value remained unchanged or was reduced. This results from the fact that the $A B C$ method, however sufficient in the calculation of operating costs, is deficient in the handling of full capital costs (Hubbell, 1996a, b).

In order to obtain complete (and therefore reliable) cost information, some authors proposed integrating the $A B C$ system with the EVA (Hubbell, 1996a, b; Roztocki and Needy, 1998; Roztocki and Needy, 1999c; Cooper and Slagmulder, 1999). EVA, a registered trademark of Stern Stewart and Company, has been implemented in numerous large companies to motivate managers to create shareholder value (Dodd and Chen, 1996). If the EVA is positive, the company creates shareholders wealth. Negative EVA indicates that shareholders wealth is destroyed (Stewart, 1991). Value-based performance measures, such as EVA and Residual Income $(R I)$, focus on capital cost and shareholders value. De facto, EVA is the same as $R I$ that has been in existence for several decades. The only significant difference between the two lies in the handling of accounting distortions (Dodd and Chen, 1997). EVA removes existing distortions by using up to 164 adjustments to traditional accounting data (Stewart, 1991; Blair, 1997). These distortions are disregarded in the $R I$ calculation. Thus, EVA helps to convert the accounting profit into economic profit by adjusting maximum accounting distortions. In this integrated costing and performance measurement system as discussed here, the $A B C$ component is used to trace overhead cost (derived from income statement), while the EVA element is used to estimate capital cost (derived from the balance sheet). Most researchers agree that the integration of an $A B C$ system and an EVA financial performance measure outperforms both traditional costing measures and the standard $A B C$, in terms of completeness and reliability of cost estimates (Hubbell, 1996a, b; Roztocki and Needy, 1998; Roztocki and Needy, 1999c; Cooper and Slagmulder, 1999).

In this paper, $A B C$ is integrated with EVA: $A B C$ allocates overhead costs over activities first then over products; and EVA allocates an equitable charge for the capital costs over the activities first by using $A C D$ analysis then over the products. Thus, the total cost of the product comprises overhead costs and capital charges as well. Products should be rightly charged; if undercharged, short-run sustainability is impossible and if overcharged, long-run sustainability is questionable. The paper concludes that integrated $A B C$-and-EVA system for pricing results competitive pricing to recover all costs related to the product and to maximize the manufacturers' economic value as well.

\section{METHODOLOGY}

The basic outcome of this article comes from secondary sources. Available literatures have been analyzed to frame the theoretical structure and then a hypothetical example is developed to visualize the applicability of the integrated system. In a value-based performance measure, like EVA, minimum profitability for retaining current investors and attracting potential investors can be calculated in terms of cost of capital $(\mathrm{COC})$ by using the following equation:

$$
C o C=A * R R R
$$

In Equation 1, $A$ represents amount of total capital invested and $R R R$ refers to the required rate of return. The $R R R$ is dependent on the risk free rate of return, market return on similar investment, risk premium, macro economic conditions, nature of business undertaken by the company, capital structure, investors' expectations and on so many factors. The $\mathrm{CoC}-$ which by nature represents an opportunity cost- includes both the cost of debt as well as that of equity which, even though it does not represent a monetary cost of production, must nevertheless be covered by revenue if the firm wants to create dividends and economic value for the shareholders (Kee, 1999). Thus, the equation for CoC can be replaced or extended by weighted average cost of capital (WACC) formulae where total capital structure is considered.

$W A C C=\frac{D}{C} \times i_{d} \times(1-t)+\frac{E}{C} \times r_{e}$

Here, $D$ represents debt, $E$ represents equity, $C$ represents capital (total of debt and equity), $i_{d}$ represents interest on debt, $t$ represents tax rate and $r_{e}$ represents cost of equity. Debt has tax deductibility capacity whereas equity has not. For calculating $r_{e}$, the following equation can be used:

$r_{e}=r_{f}+\beta\left(r_{m}-r_{f}\right)$

As an opportunity cost the aforementioned represents the yield from the use of capital with the same degree of risk, and it is estimated using the capital asset pricing model (CAPM) (Sharpe, 1964; Lintner, 1965; Mossin, 1966), according to which the cost of equity, $r_{e}$ is the algebraic sum of the yield from risk-free activities, $r_{f}$, and the expected premium for the risk. In fact, the yield from any risky activity is given by the pure interest rate (return from risk-free financial activities, for instance, treasury bills) plus the difference between the expected return from the market portfolio, $r_{m}$ and the pure interest rate, $r_{f}$, multiplied by the coefficient $\beta$ which represents a measure of the degree of non-diversifiable risk of the activity. Thus, $\beta\left(r_{m}-r_{f}\right)$ represents risk premium. The specific risk premium rate can also be developed by considering the factors affecting risk as identified above and using some scaling 
techniques like Likert (Hoque et al., 2004).

If a company is not able to show an economic profit at least as high as the capital charge, shareholders wealth is decreased (Reimann, 1988). As management considers particular investment opportunities in specific projects, products or processes, a reasonable approach would be there to divide the total capital charge among the activities while calculating cost information. If this allocation of capital charges to activities is done arbitrarily, costs could be distorted, especially in the case where capital costs are not proportional to operating costs.

$A B C$ emerged due to a similar deficiency with the arbitrary allocation of overhead costs to products. Hubbell (1996a, b) proposes combining the $A B C$ method with a value-based performance measure that includes capital costs with costs calculated under $A B C$. These capital costs, according to Hubbell, may have positive or negative values. In contrast, the integrated $A B C$-and-EVA system discussed in this paper distinguishes two different activity costs: operating cost (overheads) and capital charge (minimum profitability). Operating costs reflect the rate of resource consumption in a company, while capital charges describe the company's cost of capital invested. Operating costs and capital charges have only nonnegative values.

\section{Implementation procedure}

The implementation steps for the $A B C$ integrated EVA system are similar to those for a traditional $A B C$ system. The main difference lies in the determination of the total cost for each activity (Step 4). This step will be discussed in greater detail, while remaining steps of the implementation procedure will be discussed briefly.

\section{Step 1: Review financial statements}

The objective of this step is to identify the company's direct costs, overhead costs, and capital costs. This information can be obtained from the income statement and balance sheet. The income statement is used to identify direct costs and to estimate overhead costs, while the balance sheet is used to estimate capital costs (Roztocki and Needy, 1999a, c).

\section{Step 2: Identify main activities}

Identify the main activities describing the manufacturing and business processes of the company that consume operating resources or are responsible for capital investments. A flowchart of the company's business process (which starts, for example, with customer inquiry, and ends with final payment) is a very helpful tool for systematically identifying the activities (Roztocki et al., 1999). $A B C$ system can be refined by splitting the selected activities into more specific categories or introducing additional activities to the analysis (Cooper, 1989a).

\section{Step 3: Determine operating cost for each activity}

Calculate the operating cost for each activity in the same way as would be done for a traditional $A B C$ implementation. Costs should reflect overhead resource consumption rate by each activity.

\section{Step 4: Determine capital charge for each activity using ACD analysis}

This step does not exist in a traditional $A B C$ calculation. Since many activities consume not only resources but also capital investment, the full cost for many activities is higher than the cost calculated in an $A B C$ system. As a result, $A B C$ tends to underestimate the object cost. The integrated $A B C$-and-EVA system calculates the capital charge for activities demanding capital investments or tithing capital. This information is obtained by converting data on the company's balance sheet into capital costs or charges. These capital charges are then added to the cost for each activity previously calculated by the $A B C$ system.

\section{Step 5: Select cost drivers}

This step is similar for a traditional $A B C$ implementation. Cost drivers are used to trace the cost of activities to products based on their consumption rate. Thus, operating cost drivers can trace operating costs and capital cost drivers can trace capital charges over the products.

\section{Step 6: Calculate product cost}

Operating costs and capital costs are traced to the products to calculate the product cost.

\section{Hypothetical example}

Integrated $A B C$-and- $E V A$ methodology is exemplified in this area with reference to a small manufacturing company producing four products. The identity of the company is kept hidden due to some redundancy and typical problems. The objective of this area is to make the way clear of integrating $A B C$ with EVA. Thus, the author is more concerned with the procedure rather the distortions that should be avoided for calculating a tailored EVA, typical to the firm concerned. Some authors suggest that some items in the company's income statement, such as research and development costs, marketing outlays, and restructuring charges, should be treated as capital investments, rather than as expenses. Furthermore, equity equivalents, such as deferred income tax reserve, Last in First Out (LIFO) inventory valuation reserve, and depreciated items that represent economic book value, should be added to the company's capital (Stewart, 1991). Although this removal of accounting and financing distortions will increase system accuracy, some authors argue that this marginal gain in accuracy does not justify the additional effort (Dodd and Chen, 1996). In any event, neither inclusion nor removal of the accounting distortions changes the proposed procedure.

\section{Step 1: Review financial statements}

The company's income statement and balance sheet is presented in Tables 1 and 2, respectively from where most of the financial information for the study has been retrieved.

\section{Step 2: Identify main activities}

Main activities are identified now as shown in Table 3.

\section{Step 3: Determine operating cost for each activity}

Operating costs are calculated for each activity in Step 3. To determine the operating cost, the company's income statement was analyzed. In this example, the cost of goods sold item represents direct expenses, such as materials, supplies, and direct labor that can be traced directly to the products. Based on the data given in 
Table 1. Income statement in Thousands of Dollars

\begin{tabular}{clcc}
\hline \multicolumn{3}{c}{ Income statement } & \\
\hline S/n & Account titles & Formulae & Amount \\
\hline 1 & Net sales & & 5000 \\
2 & Cost of goods sold & $(1-2)$ & 2500 \\
3 & Gross margin & & 2500 \\
4 & Operating expenses & $(3-4)$ & 1500 \\
5 & Earnings before interest and taxes (EBIT) & & 1000 \\
6 & Interest expenses & $(5-6)$ & 200 \\
7 & Earnings before Tax (EBT) & $(7 \times 0.40)$ & 800 \\
8 & Income tax (40\%) & $(7-8)$ & 420 \\
9 & Earnings after tax (EAT) & & \\
\hline
\end{tabular}

Table 2. Balance sheet in Thousands of Dollars.

\begin{tabular}{lclc}
\hline \multicolumn{4}{c}{ Balance sheet } \\
\hline Assets & Amount & Liabilities and owners equity & Amount \\
\hline Current assets & & Current liabilities & \\
Cash & 100 & Accounts payable & 300 \\
Accounts receivable & 120 & Accrued expenses & 200 \\
Inventory & 130 & Short-term debt & 100 \\
Sundry debtors & 250 & Total current liabilities & 600 \\
Total current assets & 600 & Long-term liabilities & \\
& & & \\
Fixed assets & & Long-term debt & 1400 \\
Land & 1500 & Total long-term liabilities & 1400 \\
Building (net) & 800 & Owners' equity & \\
Equipment (net) & 700 & Capital stock & 1600 \\
Other long-term assets & 400 & Retained earnings & 400 \\
Total fixed assets & 3400 & Total owners equity & 2000 \\
Total assets & 4000 & Total liabilities and owners' equity & 4000 \\
\hline
\end{tabular}

the income statement the company's total operating cost was determined to be $\$ 1,500,000$ and was traced to the activities using a traditional $A B C$ approach. Table 4 shows the operational cost of each activity. Note that the sum of the cost of all activities is equal to the total operating cost.

\section{Step 4: Determine capital charge for each activity using ACD Analysis}

The next step is to determine the capital charge for each activity using $A C D$ Analysis. Since the company is in business to make money, the owners expect a reasonable rate of return, that is, (RRR), for their investment. Investors' expectations, management's financial objectives, as well as the company's financial structure are factors used to establish the RRR. Determining a company's desired $R R R$ is very critical. In this illustration, $R R R$ is assumed, for simplicity, to be 10 percent. Next, the company's capital, A, has to be identified from the balance sheet. The company's capital is equal to total liabilities or total asset minus all non-interest- bearing liability categories. In the example, non-interest bearing current liabilities are accounts payable and accrued expenses. In this context, capital includes both equity and debt. This approach defines capital as all money invested in a company regardless of the source (we own it - equity or we borrowed it - debt). Table 5 shows the company's $A$ calculation. The total capital is equal to $\$ 3,500,000$.

Total capital charges can now be calculated by using Equation 1 for the sake of simplicity, assuming RRR $10 \%$, as follows:

$$
\operatorname{CoC}=A+R R R=\$ 3,500,000 \times 0.10=\$ 350,000
$$

Next, total capital charges must be traced to all activities. Each activity that demands capital investment should generate a return that recovers its share of capital costs. The capital consumption rate of each activity determines the cost of the capital charge assigned to it. The cost of capital can be traced to each activity using the $A C D$ Analysis. The $A C D$ Analysis is shown in Table 6 . The rows in the $A C D$ matrix are activities (i) while the columns are the accounting categories (j) from the balance sheet. Accounting categories, in other words, represent the investment of capital into various balance sheet items. To systematically recognize the relationship between capital and activities, a checkmark at the $i, j$ 
Table 3. Activity categories and activities.

\begin{tabular}{ll}
\hline Activity categories & Activities \\
\hline $\begin{array}{l}\text { Production } \\
\text { management }\end{array}$ & $\begin{array}{l}\text { Materials issued to production } \\
\text { Production scheduling }\end{array}$ \\
$\begin{array}{l}\text { Inventory } \\
\text { management }\end{array}$ & $\begin{array}{l}\text { Inventory procurement schedule } \\
\text { 2. Inventory control }\end{array}$ \\
Administration & $\begin{array}{l}\text { Managing employees } \\
\text { Managing business }\end{array}$ \\
$\begin{array}{l}\text { Selling and } \\
\text { distribution }\end{array}$ & $\begin{array}{l}\text { Display final products } \\
\text { Shipment of final products }\end{array}$ \\
$\begin{array}{l}\text { Customer } \\
\text { management }\end{array}$ & Contact customers \\
\hline
\end{tabular}

Table 4. Operating activity cost in Thousands of Dollars.

\begin{tabular}{lc}
\hline Activities & Operating cost \\
\hline Materials issued to production & 175 \\
Production scheduling & 120 \\
Inventory procurement schedule & 135 \\
Inventory control & 168 \\
Managing employees & 222 \\
Managing business & 75 \\
Display Final Products & 95 \\
Shipment of final products & 215 \\
Contact customers & 155 \\
Billing and collection of money & 140 \\
Total operating costs & 1500 \\
\hline
\end{tabular}

Table 5. Company's Capital in Thousands of Dollars.

\begin{tabular}{lc}
\hline & Amount \\
\hline Total assets & 4000 \\
Less: Non-interest bearing current liabilities & \\
Accounts payable & $(300)$ \\
Accrues expenses & $(200)$ \\
Capital (A) & 3500 \\
\hline
\end{tabular}

entry denotes that activity $i$ uses capital from the given accounting category $j$. For example, the activity inventory control demands capital investment in inventory, land, and building. The accounts payable and accrued expenses can be considered as savings in capital requirement, because of the delayed payments in the amount of accounts payable and accrued expenses, the raising of additional capital can be offset. Next, all checkmarks in the ACD matrix are replaced with values between 0 and 1 representing the percentage of capital demanded for each activity. For instance, it was determined that only three activities; materials issued to production, production scheduling and managing business; require investments in equipment. Furthermore, it was determined that the activity materials issued to production is responsible for $70 \%$ of the investments in the company's equipment, the activity production scheduling is responsible for $20 \%$ of the investment and the activity managing business for the remaining $10 \%$. Based on this information, the corresponding checkmarks were replaced by 0.70 , 0.20 and 0.10 respectively, as shown in Table 7 .

The total capital charges (the last row in Table 7) were calculated by multiplying the particular balance sheet item by $R R R$. For example, the charge of $\$ 10,000$ for cash was obtained by multiplying the cash entry in the balance sheet of 100,000 by $R R R$ of $10 \%$. Subsequently, capital charges (the last column in Table 7 ) for all activities were calculated by adding all row entries multiplied by their respective capital charges. For example, the capital charge for the row labeled inventory control was obtained by multiplying the capital charge for inventory, 13 , by 0.10 plus the capital charge for land, 150 , times 0.10 plus the capital charge for building, 80 , times 0.10 , for a total of 24.3. By this way, the total capital charge of $\$ 350,000$ has been allocated over the activities as identified.

\section{Step 5: Select cost drivers}

Cost drivers are selected in Step 5. The operating cost drivers of the concerned company are identified in Table 8 that may also be used as capital cost drivers in this case. Because, the operation and capital requirements shows a positive relationship in this small manufacturing company, On the basis of these cost drivers, total operating costs and capital charges can easily be allocated over the four products.

\section{Step 6: Calculate product cost}

To obtain the total cost for each activity the operating cost and capital charge must be summed. Table 9 shows activities with operating costs and capital charges. Some of the activities became significantly more expensive.

Now, the product costs is calculated in Table 10 under conventional $\mathrm{ABC}$ system by allocating only operating costs over the four products and presented in the form of an income statement. In Table 11, this allocation is revised under integrated $A B C$-and-EVA system where both operating cost and capital charges are allocated over the four products and presented in a similar fashion.

\section{RESULTS}

Although, the $A B C$ method provides accurate operating product costs, it does not identify which products are economic value added creators and so contribute to stockholders' wealth. On the first look, including capital charges in product cost information increase their cost, in some cases significantly. On the other hand, the managers obtain a powerful tool. For example, the illustration shows that if management uses the product costs obtained using the $A B C$ system, they will conclude that Products 1 and 4 is more profitable than Products 2 and 3 . If, however, they use the product costs obtained using the integrated $A B C$-and- EVA system, management can see which products create value. In the 
Table 6. Activity-capital dependence $(A C D)$ analysis.

\begin{tabular}{|c|c|c|c|c|c|c|c|c|c|c|}
\hline \multirow[b]{2}{*}{ Activities (i) } & \multicolumn{10}{|c|}{ Accounting category (j) } \\
\hline & Cash & $\begin{array}{l}\text { Accounts } \\
\text { receivable }\end{array}$ & Inventory & $\begin{array}{l}\text { Sundry } \\
\text { debtors }\end{array}$ & Land & Building & Equipment & $\begin{array}{l}\text { Other long- } \\
\text { term assets }\end{array}$ & $\begin{array}{c}\text { Accounts } \\
\text { payable }\end{array}$ & $\begin{array}{c}\text { Accrued } \\
\text { expenses }\end{array}$ \\
\hline Materials issued to production & & & $\sqrt{ }$ & & $\sqrt{ }$ & $\sqrt{ }$ & $\sqrt{ }$ & & & \\
\hline Production scheduling & & & & & $\sqrt{ }$ & $\sqrt{ }$ & $\sqrt{ }$ & & & \\
\hline Inventory procurement schedule & $\sqrt{ }$ & $\sqrt{ }$ & $\sqrt{ }$ & & $\sqrt{ }$ & $\sqrt{ }$ & & & $\sqrt{ }$ & \\
\hline Inventory control & & & $\sqrt{ }$ & & $\sqrt{ }$ & $\sqrt{ }$ & & & & \\
\hline Managing employees & $\sqrt{ }$ & & & & $\sqrt{ }$ & $\sqrt{ }$ & & & & $\sqrt{ }$ \\
\hline Managing business & $\sqrt{ }$ & $\sqrt{ }$ & $\sqrt{ }$ & $\sqrt{ }$ & $\sqrt{ }$ & $\sqrt{ }$ & $\sqrt{ }$ & $\sqrt{ }$ & & $\sqrt{ }$ \\
\hline Display final products & & & $\sqrt{ }$ & & $\sqrt{ }$ & $\sqrt{ }$ & & $\sqrt{ }$ & & \\
\hline Shipment of final products & & & $\sqrt{ }$ & & $\sqrt{ }$ & $\sqrt{ }$ & & $\sqrt{ }$ & & \\
\hline Contact customers & & $\sqrt{ }$ & $\sqrt{ }$ & & $\sqrt{ }$ & $\sqrt{ }$ & & & & \\
\hline Billing and collection of money & $\sqrt{ }$ & $\sqrt{ }$ & & $\sqrt{ }$ & $\sqrt{ }$ & $\sqrt{ }$ & & & & \\
\hline
\end{tabular}

Table 7. Activity-capital dependence $(A C D)$ analysis in Thousands of Dollar.

\begin{tabular}{|c|c|c|c|c|c|c|c|c|c|c|c|}
\hline \multirow[b]{2}{*}{ Activities (i) } & \multicolumn{10}{|c|}{ Accounting category (j) } & \multirow{2}{*}{$\begin{array}{l}\text { Activity } \\
\text { capital } \\
\text { charge }\end{array}$} \\
\hline & Cash & $\begin{array}{l}\text { Accounts } \\
\text { receivable }\end{array}$ & Inventory & $\begin{array}{l}\text { Sundry } \\
\text { debtors }\end{array}$ & Land & Building & Equipment & $\begin{array}{l}\text { Other long- } \\
\text { term assets }\end{array}$ & $\begin{array}{c}\text { Accounts } \\
\text { payable }\end{array}$ & $\begin{array}{c}\text { Accrued } \\
\text { expenses }\end{array}$ & \\
\hline Materials issued to production & & & 0.2 & & 0.1 & 0.1 & 0.7 & & & & 74.6 \\
\hline Production scheduling & & & & & 0.1 & 0.1 & 0.2 & & & & 37.0 \\
\hline Inventory procurement schedule & 0.1 & 0.5 & 0.1 & & 0.1 & 0.1 & & & 1.0 & & 01.3 \\
\hline Inventory control & & & 0.1 & & 0.1 & 0.1 & & & & & 24.3 \\
\hline Managing employees & 0.2 & & & & 0.1 & 0.1 & & & & 0.5 & 15.0 \\
\hline Managing business & 0.1 & 0.1 & 0.1 & 0.2 & 0.1 & 0.1 & 0.1 & 0.4 & & 0.5 & 44.5 \\
\hline Display final products & & & 0.1 & & 0.1 & 0.1 & & 0.3 & & & 36.3 \\
\hline Shipment of final products & & & 0.3 & & 0.1 & 0.1 & & 0.3 & & & 38.9 \\
\hline Contact customers & & 0.1 & 0.1 & & 0.1 & 0.1 & & & & & 25.5 \\
\hline Billing and collection of money & 0.6 & 0.3 & & 0.8 & 0.1 & 0.1 & & & & & 52.6 \\
\hline Total capital charge & 10 & 12 & 13 & 25 & 150 & 80 & 70 & 40 & -30 & -20 & 350 \\
\hline
\end{tabular}

illustration, Product 3 , which under the $A B C$ system was regarded as creating minor value for the company, yields higher levels of economic profit due to its limited use of capital. In contrast, Product 1 is consuming more resources resulting the highest operating expenses and demanding high capital investments. This capital demand results in a relatively high capital charge. More accurate product cost information alone, however, does not automatically lead to improvements in business performance. Once product cost information is obtained from the integrated $A B C$ and-EVA system, management is challenged to take action. For example, some possible strategies regarding Product 1 include: 
Table 8. Activities identified with respective cost drivers.

\begin{tabular}{ll}
\hline Activities & Cost drivers \\
\hline Materials issued to production & Dollar value of materials issued \\
Production scheduling & Number of setups, processing time \\
Inventory procurement schedule & Number of suppliers \\
Inventory control & Use of storage capacity \\
Managing employees & Number of employees \\
Managing business & Dollar value of sales \\
Display final products & Number of outlets \\
Shipment of final products & Number of orders shipped \\
Contact customers & Number of customers \\
Billing and collection of money & Dollar value of credit sales \\
\hline
\end{tabular}

Table 9. Operating costs and capital charges in Thousands of Dollar.

\begin{tabular}{lccc}
\hline Activities & Operating cost & Capital charges & Total cost \\
\hline Materials issued to production & 175 & 74.6 & 249.6 \\
Production scheduling & 120 & 37.0 & 157.0 \\
Inventory procurement schedule & 135 & 01.3 & 136.3 \\
Inventory control & 168 & 24.3 & 192.3 \\
Managing employees & 222 & 15.0 & 237.0 \\
Managing business & 75 & 44.5 & 119.5 \\
Display final products & 95 & 36.3 & 131.3 \\
Shipment of final products & 215 & 38.9 & 253.9 \\
Contact customers & 155 & 25.5 & 180.5 \\
Billing and collection of money & 140 & 52.6 & 192.6 \\
Total & 1500 & 350 & 1850 \\
\hline
\end{tabular}

Table 10. Product cost calculation using ABC system in Thousands of Dollars.

\begin{tabular}{lccccc}
\hline \multicolumn{2}{c}{ ABC } & & & & \\
\hline Products & $\mathbf{1}$ & $\mathbf{2}$ & $\mathbf{3}$ & $\mathbf{4}$ & Total \\
\hline Net sales & 2000 & 1200 & 1000 & 800 & 5000 \\
Costs of goods sold (directly traced) & 1100 & 700 & 500 & 200 & 2500 \\
Operating expenses (allocated on cost drivers) & 500 & 400 & 300 & 300 & 1500 \\
Interest expense & 80 & 40 & 40 & 40 & 200 \\
Profit before tax & 320 & 60 & 160 & 260 & 800 \\
Income tax & 128 & 24 & 64 & 104 & 320 \\
Profit after tax & 192 & 36 & 96 & 156 & 480 \\
\hline
\end{tabular}

1. Increase the selling price, if possible

2. Decrease its capital demand

3. Reduce the operating costs

4. Increase the output with only minimal additional capital investments, keeping operational cost in line

5. Search for a replacement product having a better potential to be a value creator

6. Drop it and turn attention to other products like Product 2.

In addition, management may need to reconsider its attitude toward Product 3 , which appears to be more attractive under the $A B C$-and-EVA system. For example, management may wish to increase marketing efforts for Product 3.

\section{Conclusions}

Integrated $A B C$-and-EVA system will help managers in companies understand that the capital invested in their company is a precious resource that has to be used effectively. Here, capital charge added to activities and traced to the products attempts to account for the capital 
Table 11. Product cost calculation using ABC-and-EVA system in Thousands of Dollars.

\begin{tabular}{lccccc}
\hline \multicolumn{7}{c}{ Integrated ABC-and-EVA system } \\
\hline Products & $\mathbf{1}$ & $\mathbf{2}$ & $\mathbf{3}$ & $\mathbf{4}$ & Total \\
\hline Net Sales & 2000 & 1200 & 1000 & 800 & 5000 \\
Costs of goods sold (directly traced) & 1100 & 700 & 500 & 200 & 2500 \\
Operating expenses (allocated on cost drivers) & 500 & 400 & 300 & 300 & 1500 \\
Operating income & 400 & 100 & 200 & 300 & 1000 \\
Income tax (allocated in proportion to income) & 128 & 32 & 64 & 96 & 320 \\
Profit After tax & 272 & 68 & 136 & 204 & 680 \\
Capital charge & 180 & 20 & 30 & 120 & 350 \\
Profit after tax & 92 & 48 & 106 & 84 & 330 \\
\hline
\end{tabular}

use and helps management understand the capital cost associated with the manufacturing process. Management can obtain a distorted impression of profitability if they look only at profit after tax in the traditional sense as opposed to economic profit as calculated in the integrated $A B C$-and- $E V A$ system. Once implemented, the integrated $A B C$-and-EVA system can be used as an engineering management tool to protect company leaders from making short-term decisions based on profit alone that may destroy economic value over the longterm.

The integrated $A B C$-and-EVA system by itself will not make improvements in the business process, but rather will provide management with information that can direct improvement efforts. Management should be committed to make these necessary improvement steps.

In most cases, the benefits of using the integrated $A B C$-and-EVA system outweigh the expenses and efforts needed for implementation. This system, in order to support a successful decision-making team, needs, however, the benefit of up-to-date cost information. Therefore, many companies may choose to use the integrated $A B C$-and-EVA information system (Roztocki, 2000a), which more effectively captures all fluctuation in direct, overhead, and capital costs, and provides more reliable, complete and up-to-date product cost estimates.

\section{REFERENCES}

Blair A (1997). EVA Fever. Management Today, January, pp. 42-45.

Cooper R (1988a). The Rise of Activity-Based Costing-Part One: What is an Activity-Based Cost System? J. Cost Manage. Summer pp. 4554.

Cooper R (1988b). The Rise of Activity-Based Costing - Part Two: When Do I Need an Activity-Based Cost System? J. Cost Manag. Fall pp. 41-58.

Cooper R (1989a). The Rise of Activity-Based Costing - Part Three: How Many Cost Drivers Do You Need, and How Do You Select Them? J. Cost Manage. Winter pp. 34-46.

Cooper R (1989b). The Rise of Activity-Based Costing - Part Four: What Do Activity-Based Cost Systems Look Like? J. Cost Manag. Spring pp. 38-49.

Cooper R, Kaplan RS (1988). Measure Cost Right: Make the Right Decisions. Harv. Bus. Rev. September-October pp. 96-102.
Cooper R, Kaplan RS (1991). Profit Priorities from Activity Based Costing. Harv. Bus. Rev. pp. 130-135.

Cooper R, Slagmulder R (1999). Integrating Activity Based Costing and Economic Value Added. Manag. Account. 80(7):16-17.

Dearden J (1963). Profit-Planning Accounting for Small Firms. Harv. Bus. Rev. 41(2):66-76.

Dodd JL, Chen S (1996). EVA: A New Panacea? B\&E Review, JulySeptember pp. 26-28.

Dodd JL, Chen S (1997). Economic Value Added (EVA). Arkansas Bus. Econ. Rev. Winter pp. 1-8.

Hoque M Akter M, Shil NC (2004). Value-based Measure: An Application of EVA in Small Manufacturing Company in Bangladesh, J. Inst. Bankers Bangladesh, July-December 51(2):135-155.

Hubbell WW (1996a). Combining Economic Value Added and ActivitiesBased Management. J. Cost Manage. Spring 10(1):18-29.

Hubbell WW (1996b). A Case Study in Economic Value Added and Activities-Based Management. J. Cost Manag. Summer 10(2):20-29.

Kee RC (1999). Using Economic Value Added with ABC to enhance your Production-related decision making. J. Cost Manag. pp. 3-15.

Lintner J (1965). The valuation of risky assets and the selection of risky investments in stock portfolios and capital budget. Rev. Econom. Stat. 54(1):87-89.

Mossin J (1966). Equilibrium in a capital market. Econometrica $34(4): 768-783$

Reimann BC (1988). Managing for The Shareholder: An Overview of Value-Based Planing. January-February Plann. Rev. pp. 10-22.

Roztocki N (2000a). The Integrated Activity-Based Costing and Economic Value Added Information System. Proceedings from the 2000 SAM International Management Conference.

Roztocki N, Needy KL (1998). An Integrated Activity Based Costing and Economic Value Added System as an Engineering Management Tool for Manufacturers. Proceedings from the 1998 ASEM Natl. Conf. pp. 77-84.

Roztocki N, Needy KL (1999a). EVA for Small Manufacturing Companies. Proceedings from the 1999 SAM Int. Manag. Conf. pp. 461-469.

Roztocki N, Needy KL (1999b). How to Design and Implement an Integrated Activity Based Costing and Economic Value Added System. Proceedings from the Industrial Engineering Research '99 Conference, CD pp. 1-12.

Roztocki N, Needy KL (1999c). Integrating Activity Based Costing and Economic Value Added in Manufacturing. June Eng. Manag. J. 11(2):17-22.

Roztocki N, Valenzuela JF, Porter JD, Monk RM, Needy KL (1999). A Procedure for Smooth Implementation of Activity Based Costing in Small Companies. Proceedings from the 1999 ASEM National Conference pp. 279-288.

Sharpe WF (1964). Capital Asset Prices: a theory of market equilibrium in conditions of risk. J. Finan. 19(3):425-442.

Stewart GB (1991). The Quest for Value: A Guide for Senior Managers. Harper Bus. pp. 137-188. 